\title{
The Acute and Delayed Mortality of the Northern Krill (Meganyctiphanes norvegica) When Exposed to Hydrogen Peroxide
}

\author{
Rosa H. Escobar-Lux ${ }^{1}$ [D . Ole B. Samuelsen ${ }^{2}$
}

Received: 2 July 2020 / Accepted: 14 September 2020 / Published online: 26 September 2020

(c) The Author(s) 2020

\begin{abstract}
Bath treatment pharmaceuticals used to control sea lice infestations in the salmonid industry, such as hydrogen peroxide $\left(\mathrm{H}_{2} \mathrm{O}_{2}\right)$, are released directly into the environment where non-target organisms are at risk of exposure. The aim of this study was to determine the threshold concentrations for mortality of the Northern krill, Meganyctiphanes norvegica, a major component of the north Atlantic marine ecosystem. To assess the lethal effects of $\mathrm{H}_{2} \mathrm{O}_{2}$, we carried out a series of $1 \mathrm{~h}$ acute toxicity tests and assessed mortality through a $48 \mathrm{~h}$ post-exposure period. One-hour exposure to $170 \mathrm{mg} / \mathrm{L}$, corresponding to $10 \%$ of the recommended $\mathrm{H}_{2} \mathrm{O}_{2}$ treatment, caused $100 \%$ mortality and a subsequent acute median-lethal concentration LC50 value of $32.5 \mathrm{mg} / \mathrm{L}$. Increased mortality was observed with time in all exposed groups, resulting in successively lower $\mathrm{LC}_{50}$ values during the post-exposure period. The suggested $\mathrm{H}_{2} \mathrm{O}_{2}$ concentrations have the potential of causing negative effects to the Northern krill.
\end{abstract}

Keywords Crustacean $\cdot$ Toxicity $\cdot \mathrm{LC}_{50} \cdot$ Aquaculture

Sea lice (Lepeophtheirus salmonis and Caligus rogercresseyi), naturally occurring parasitic copepods affecting both farmed and wild salmonid populations, are a major challenge for the salmonid industry worldwide (Costello 2006; Torrissen et al. 2013; Vollset et al. 2016). The parasites feed on the mucous, skin, and blood of its host, and if present in significant numbers they can cause damage associated with osmotic stress and secondary infections (Finstad et al. 2000; Johnson et al. 2004; González et al. 2015). Norwegian wild salmonid populations, migrating post smolts from Atlantic salmon and local populations of sea trout (Salmon trutta), can suffer high mortality if there is high density of salmon lice larvae in the surrounding water (Costello 2009; Vollset et al. 2016). In farmed fish, salmon lice infestations reduce the general welfare of the fish and lead to an increase of the overall cost of the industry due to reduced growth and marketability due to skin lesions, and high costs associated with delousing treatments (Costello 2009). Therefore, both

Rosa H. Escobar-Lux

rosa.escobar@hi.no

1 Institute of Marine Research, Austevoll Research Station, Sauganeset 16, 5392 Storeb $\varnothing$, Norway

2 Institute of Marine Research, Nordnes, P.O. Box 1870, 5817 Bergen, Norway the economic and ecological impact of salmon lice infestations are significant challenges for the salmonid industry.

In order to control salmon lice infestations, the industry has relied on the use of different chemotherapeutants, through the application of bath treatments and the use of infeed drugs. Bath treatments can be applied either by enclosing the fish cages with an impervious tarpaulin or transferring the fish into well-boats, and after treatment the waste water is directly released into the surrounding water (Ernst et al. 2001; Burridge et al. 2010). At a global level, hydrogen peroxide $\left(\mathrm{H}_{2} \mathrm{O}_{2}\right)$ was introduced as an antiparasitic agent after the loss of sensitivity in both $L$. salmonis and $C$. rogercresseyi to other delousing agents (Bravo et al. 2015; Urbina et al. 2019). In Norway alone, $\mathrm{H}_{2} \mathrm{O}_{2}$ is still the most used bath treatment therapeutant with a consumption of 4523 tons in 2019 (www.fhi.no/hn/legemiddelbruk).

Hydrogen peroxide acts on salmon lice by hydroxyl radicals attacking lipid and cellular organelles resulting in inactivation of enzymes and DNA replication (Cotran et al. 1989; Urbina et al. 2019). Previous studies have also shown that decomposition of hydrogen peroxide to water and $\mathrm{O}_{2}$ bubbles in the gut and the haemolymph may cause mechanical paralysis leading to detachment of the preadult and adult salmon lice from the fish and causing them to float towards the surface (Bruno and Raynard 1994; 
Aaen et al. 2014). A bath treatment involves the release of a large volume of $\mathrm{H}_{2} \mathrm{O}_{2}$ containing waste water and the chemical can potentially be dispersed over a wide area (Burridge et al. 2010, 2014, Parsons et al. 2020, Refseth et al. 2017). Therefore, there is a growing concern about the possible toxic effects of $\mathrm{H}_{2} \mathrm{O}_{2}$ on non-target aquatic invertebrate species living in the vicinity of fish farms, and specifically crustaceans which has been proven as particularly vulnerable (Smit et al. 2008; Burridge et al. 2014; Van Geest et al. 2014; Gebauer et al. 2017; Hansen et al. 2017; Bechmann et al. 2019; Escobar-Lux et al. 2019).

The pelagic zooplankton, Meganyctiphanes norvegica, Northern krill, is a species at risk as its distribution overlaps with the location to many salmon farms in Norway, as it inhabits both coastal and offshore waters (Kaartvedt et al. 2002; Melle et al. 2004; Tarling et al. 2010). Furthermore, the distribution of this boreal krill species has been described to be seasonal, with a predominant coastal distribution between the months of January and May (Grover 1952). In Norway, during this period of the year, pharmaceuticals are being used to keep the level of salmon lice below 0.2 female lice per fish as specified in the Norwegian Ministry of Trade, Industry and Fisheries (FOR-2012-12-05-1140, 2012) (Grefsrud et al. 2019). The total biomass of euphasiid stocks in the Norwegian Sea has been previously estimated to 42 million tons (Mt), with around $40-75 \%$ of this stock being Northern krill (Lindley 1982; Melle et al. 2004). Thus, the northern krill is a major component of the north Atlantic marine ecosystem, acting as a keystone organism between lower trophic levels and larger predators and plays an important role in the sequestration of carbon (Kaartvedt et al. 2005; Tarling et al. 2010). It is preyed upon by several commercially important fish species (Sameoto et al. 1994; Onsrud et al. 2004), seabirds (Montevecchi et al. 1992; Stevick et al. 2008), and marine mammals (Brodie et al. 1978). Moreover, the commercial exploitation of Northern krill is gaining interest in the salmonid industry as a potential protein alternative to the fishmeal (Tarling et al. 2010). Mass death of krill washed up on a beach can occur and is considered a natural phenomenon. Previously the mass stranding of $M$. norvegica has been explained as predation events in which predators' chase krill ashore (MacDonald 1927), transported to land by oceanic currents or by special events like upwellings (Aitken 1960; Cox 1975), or because special lightning conditions that might interfere with the krill's behavior (Wiborg 1966). However, in recent years there has been a higher frequency of reports in Norway describing this phenomenon near areas with salmon farms. This started a debate in public media of what might have caused the mass mortality and one of the most frequently cited suggestions has been the use of pesticides for delousing of the salmon farms, and especially $\mathrm{H}_{2} \mathrm{O}_{2}$. However, the effects of $\mathrm{H}_{2} \mathrm{O}_{2}$ exposure on the Northern krill have until now been unknown.

For treating salmon, the recommended concentration for a $\mathrm{H}_{2} \mathrm{O}_{2}$ bath treatment is $1500-2100 \mathrm{mg} / \mathrm{L}$ for $20 \mathrm{~min}$ depending on temperature (https://www.felleskatalogen.no/medis in-vet). Typically, toxicity studies use exposure times that vary from 24 to $96 \mathrm{~h}$. However, these may not be representative of the real-life scenarios following a release of waste water after a bath treatment on a salmon farm (Ernst et al. 2001; Urbina et al. 2019). The use of $1 \mathrm{~h}$ exposures, is considered a more realistic exposure scenario, but to date only a limited number of species have been tested under those conditions (Medina et al. 2004; Fairchild et al. 2010; Burridge et al. 2014; Van Geest et al. 2014; Escobar-Lux et al. 2019; Parsons et al. 2020). What these previous studies also have shown is that the mortality observed immediately after exposure tends to be lower than the mortalities registered if a post-exposure period is included in the experimental setup. A longer post-exposure observation period is therefore recommended.

The main objective of this study was to examine the toxicity of $\mathrm{H}_{2} \mathrm{O}_{2}$ to $M$. norvegica, a non-target crustacean and keystone species of the Norwegian marine environment. Our objective was to expose the Northern krill to a short $1 \mathrm{~h}$ pulse of $\mathrm{H}_{2} \mathrm{O}_{2}$ and assess the acute and delayed mortality during a post-exposure period of $48 \mathrm{~h}$ in clean seawater.

\section{Materials and Methods}

In the present study, krill (M. norvegica) were collected from the dock at Austevoll Research Station, Institute of Marine Research Norway $\left(60^{\circ} 05^{\prime} 20^{\prime \prime} \mathrm{N} 5^{\circ} 15^{\prime} 57^{\prime \prime} \mathrm{E}\right)$ using light traps. The light traps (mesh size $500 \mu \mathrm{m} ; 0.45 \mathrm{~m}$ in diameter; BellaMare USA) were equipped with a white LED light and deployed at a depth of $20 \mathrm{~m}$ overnight. The research station is at least $3 \mathrm{~km}$ away from the nearest commercial salmon farm. Krill from the traps were transported to the laboratory at Austevoll Research Station and kept overnight in $10 \mathrm{~L}$ buckets supplied with sand filtered seawater from a depth of $160 \mathrm{~m}$ (Bjørnafjorden) holding a temperature of $8{ }^{\circ} \mathrm{C}$ (salinity of $34.2 \mathrm{ppt}$; $\mathrm{pH}$ 7.94). The experiment was performed within $48 \mathrm{~h}$ of capture and prior to exposure the krill were sorted and only krill in excellent physical condition were used in the experiments.

Commercial $\mathrm{H}_{2} \mathrm{O}_{2}$ (Nemona, Akzo Nobel Pulp and Performance Chemicals $\mathrm{AB}$ Sweden) at a concentration of 49.50\% (600 g/L) was purchased from Akzo Nobel, Pulp and Performance Chemicals, AB Sweden. Since no previous studies had assessed the toxicity of $\mathrm{H}_{2} \mathrm{O}_{2}$ on M. norvegica, the chosen concentrations were based on the recommended dose for treating salmon $(1700 \mathrm{mg} / \mathrm{L})$. The krill were exposed to concentrations of 1.7, 8.5, 17, 170, 850 and 
$1700 \mathrm{mg} / \mathrm{L} \mathrm{H}_{2} \mathrm{O}_{2}$, corresponding to $0.1,0.5,1,10,50$ and $100 \%$ of the recommended treatment dose. All exposures were conducted in glassware units with a volume of $500 \mathrm{~mL}$. A total of 140 krill were randomly divided into seven treatment groups, including a control group, with four replicates for each treatment and each replicate counting five individuals. After the $1 \mathrm{~h}$ exposure, acute mortality was recorded and the krill were transferred to $10 \mathrm{~L}$ recovery tanks where mortality was checked successively at 6,24 and $48 \mathrm{~h}$ post-exposure using a dissecting microscope. Krill were considered dead if there was no movement of the pereopods, pleopods or antenna after a gentle stimulus. Mortality that occurred during the $1 \mathrm{~h}$ exposure was defined as acute mortality. Total mortality was defined as the cumulative mortality after the $48 \mathrm{~h}$ post-exposure period.

The statistical analyses for mortality were done in the software R (Version 3.5.3 (2019-03-11) Copyright @ 2019 The R Foundation for Statistical Computing). The $\mathrm{LC}_{50}$ values, and their $95 \%$ confidence intervals $(\mathrm{CI})$, were calculated using generalized linear models (GLM) with binomial error structures and probit links, according to Finney (1971). Hydrogen peroxide concentrations were $\log 10$ transformed to linearize the data.
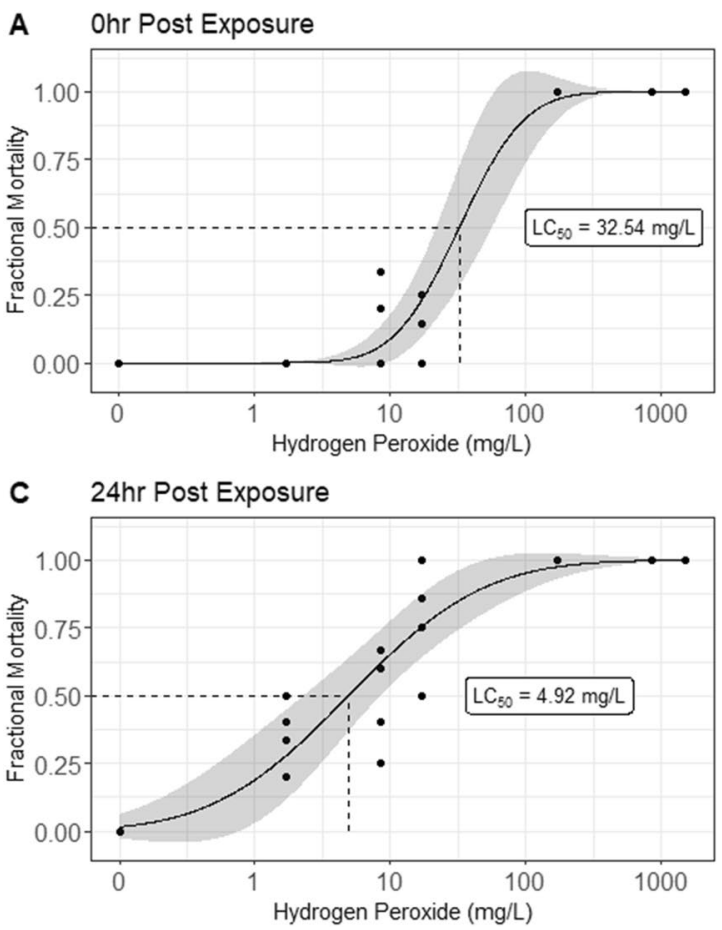

Fig. 1 The toxicity of hydrogen peroxide to M. norvegica following $1 \mathrm{~h}$ exposure. Dose-response curves showing mortality amongst the northern krill at $0 \mathrm{~h}, 6 \mathrm{~h}, 24 \mathrm{~h}$, and $48 \mathrm{~h}$ post-exposure to $\mathrm{H}_{2} \mathrm{O}_{2}$. Each point on the graphs represent an individual replicate tank containing

\section{Results and Discussion}

This study clearly show that $\mathrm{H}_{2} \mathrm{O}_{2}$ was acutely toxic to wildcaptured Northern krill M. norvegica. While no mortality was recorded in the group exposed to the lowest dose of $1.7 \mathrm{mg} / \mathrm{L}$ or in the control group, a $1 \mathrm{~h}$ exposure to $170 \mathrm{mg} / \mathrm{L}$, i.e. $10 \%$ of recommended dose, caused $100 \%$ mortality and a subsequent acute $\mathrm{LC}_{50}$ value of $32.5 \mathrm{mg} / \mathrm{L}(16.8-48.2)$ was calculated (Fig. 1a). During the post-exposure period, increased mortality with time was observed in all exposed groups resulting in successively lower $\mathrm{LC}_{50}$ values with $14.11 \mathrm{mg} / \mathrm{L}$ after $6 \mathrm{~h}$ (7.3-20.9), $4.92 \mathrm{mg} / \mathrm{L}(1.2-7.9)$ after $24 \mathrm{~h}$ and finally $0.86 \mathrm{mg} / \mathrm{L}$ after $48 \mathrm{~h}$ (Fig. $1 \mathrm{~b}-\mathrm{d}$ ). No mortality was registered in the control groups during the postexposure period. The calculated $\mathrm{LC}_{50}$ value at $24 \mathrm{~h}$ represents a threefold dilution of the acute $1 \mathrm{~h} \mathrm{LC}_{50}$ value. These findings clearly support the recommendations suggested in previous studies to include a post-exposure period following the exposure to $\mathrm{H}_{2} \mathrm{O}_{2}$ to assess any delayed effects (Van Geest et al. 2014; Brokke 2015; Escobar-Lux et al. 2019).

While several studies have examined the toxicity of $\mathrm{H}_{2} \mathrm{O}_{2}$ on marine crustacean species, the number of
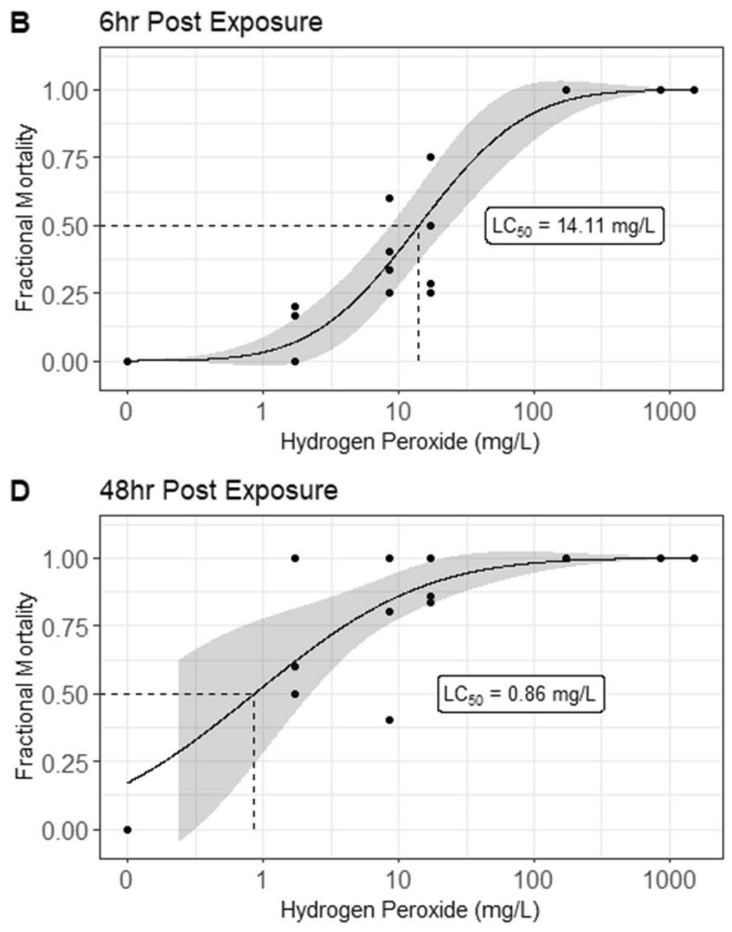

4 to 6 krill and the line represent the best fit model for the data calculated using a binomial log-probit GLM in R. The shadowed area represents the $95 \%$ confidence intervals

studies using an exposure time of $1 \mathrm{~h}$ is more limited. A review of those studies reveals that some crustaceans 
have a relatively high tolerance to $\mathrm{H}_{2} \mathrm{O}_{2}$ exposure and is reflected in low mortality when exposed to concentrations similar to or higher than the recommended treatment dose. This applies to both newly hatched larvae and adult of American lobster (Homarus americanus), sand shrimp (Crangon septemspinosa), the mysid Mysid sp. (Burridge et al. 2014), rock pool shrimp (Palaemon elegans) and chameleon shrimp (Praunus flexuosus) (Brokke 2015). For some species, low mortality was observed even when a post-exposure period was included in the study. Following an exposure of $1 \mathrm{~h}$ and a $95 \mathrm{~h}$ post-exposure period, the calculated $\mathrm{LC}_{50}$ values were $1673 \mathrm{mg} / \mathrm{L}$ for $H$. americanus larvae, $>3750 \mathrm{mg} / \mathrm{L}$ for adult American lobster, $3182 \mathrm{mg} / \mathrm{L}$ for sand shrimps and $973 \mathrm{mg} / \mathrm{L}$ for Mysid sp. (Burridge et al. 2014; Van Geest et al. 2014). For rock pool shrimps and chameleon shrimps the acute mortality after $1 \mathrm{~h}$ exposure was low indicating $\mathrm{LC}_{50}$ values higher than the highest exposure concentration of $1700 \mathrm{mg} / \mathrm{L}$ for both species (Brokke 2015). However, a significant mortality occurred during the $24 \mathrm{~h}$ post-exposure period, resulting in $\mathrm{LC}_{50}$ values of $174.1 \mathrm{mg} / \mathrm{L}$ and $77.5 \mathrm{mg} / \mathrm{L}$ for rock pool shrimp and chameleon shrimps respectively, classifying these species as highly sensitive. In the study by Bechmann et al. (2019), the Northern shrimp (Pandalus borealis) was exposed to $15 \mathrm{mg} / \mathrm{L} \mathrm{H}_{2} \mathrm{O}_{2}$ for $1 \mathrm{~h}$. The very low acute mortality observed immediately after exposure did however increase during the post-exposure period ( 7 days) but as the total mortality never exceeded $30 \%$, no $\mathrm{LC}_{50}$ could be calculated. Damage on the gills was observed in the shrimps exposed to $\mathrm{H}_{2} \mathrm{O}_{2}$ and suggested as the major cause of the delayed mortality (Bechmann et al. 2019).

In comparison, species like the copepods Acartia Hudsonica and Calanus spp. have shown higher sensitivity to $\mathrm{H}_{2} \mathrm{O}_{2}$ exposure, resulting in $\mathrm{EC}_{50}$ and $\mathrm{LC}_{50}$ values of $2.6-10 \mathrm{mg} / \mathrm{L}$ and $30.6 \mathrm{mg} / \mathrm{L}$ respectively, following a $24 \mathrm{~h}$ post-exposure period (Van Geest et al. 2014; Escobar-Lux et al. 2019). In the case of the European lobster (Homarus gammarus) larvae (stage I-IV), a $1 \mathrm{~h}$ exposure to $1530 \mathrm{mg} / \mathrm{L}$ followed by a $24 \mathrm{~h}$ post-exposure period, resulted in mortalities between 75 and 100\% (Escobar-Lux et al. 2020) and calculated $\mathrm{LC}_{50}$ values of $177 \mathrm{mg} / \mathrm{L}, 404 \mathrm{mg} / \mathrm{L}, 676 \mathrm{mg} / \mathrm{L}$ and $738 \mathrm{mg} / \mathrm{L}$, for stages I, II, III and IV respectively. For species other than crustaceans, the polychaete Ophryotrocha sp. and the sugar kelp Saccharina latissima are amongst the more sensitive marine species with $\mathrm{LD}_{50}$ values of $64.3 \mathrm{mg} / \mathrm{L}$ and $80.7 \mathrm{mg} / \mathrm{L}$ following $72 \mathrm{~h}$ and 7 days' post-exposure periods, respectively (Fang et al. 2018; Haugland et al. 2019). The $\mathrm{LC}_{50}$ values calculated for northern krill are therefore, to our knowledge the most sensitive species examined so far.

This study has shown that a bath treatment with $\mathrm{H}_{2} \mathrm{O}_{2}$ has a detrimental effect on $M$. norvegica. However, it is important to assess whether these laboratory-based concentrations are likely to pose a significant risk to krill at the proximity of salmonid aquaculture sites. Due to differences in experimental set-ups the variation in halflives reported for $\mathrm{H}_{2} \mathrm{O}_{2}$ in seawater in large, with results between 1 and 58 days (Bruno and Raynard 1994; Lyons et al. 2014; Fagereng 2016; Parsons and Samuelsen unpubl. data). Several factors affect both the toxicity and the degradation of $\mathrm{H}_{2} \mathrm{O}_{2}$, for example the water temperature or the irradiance (Stratford et al. 1984; Treasure et al. 2000)". However, even the shortest degradation time reported ( 1 day) is significantly longer than the $1 \mathrm{~h}$ exposure needed in the present study to cause considerable mortality of the Northern krill. Even though $\mathrm{H}_{2} \mathrm{O}_{2}$ is extensively used around the world as an anti-sea lice bath treatment, few studies have initiated the use of mathematical models to predict its' dispersal and its' impact on non-target species. One such study from Norway has indicated that the spread of $\mathrm{H}_{2} \mathrm{O}_{2}$ may be larger than previously thought (Refseth et al. 2017). According to the model, concentrations up to $300 \mathrm{mg} / \mathrm{L}$ may occur within a $1 \mathrm{~km}$ radius from the farm and $100 \mathrm{mg} / \mathrm{L}$ within a radius of $2 \mathrm{~km}$. Furthermore, the model also suggested that a concentration of $100 \mathrm{mg} / \mathrm{L}$ can be present in surface waters for several hours after discharge. The presented model simulations therefore suggest that the Northern krill within $2 \mathrm{~km}$ of a salmonid farm may be exposed to lethal concentration of $\mathrm{H}_{2} \mathrm{O}_{2}$.

Parsons et al. (2020) used dispersion models to predict the spreading of pharmaceuticals from salmonid farms in Norway, following bath treatment. Based on the models and $\mathrm{LC}_{50}$ values ( $1 \mathrm{~h}$ exposure followed by $24 \mathrm{~h}$ post-exposure period) for European lobster larvae (stage I and II) they calculated impact zones around 23 Norwegian fish farms for the pesticides azamethiphos and deltamethrin. This model however, did not take into account the degradation of the compounds due to the presence of organic matter in the water. While the azamethiphos impact zones around farms were relatively small (mean area of $0.04-0.2 \mathrm{~km}^{2}$ ), deltamethrin impact zones covered much larger areas (mean area of $21.1-39.0 \mathrm{~km}^{2}$ ). The difference in impact zone is due to the difference in toxicity between the two drugs. For azamethiphos the $1 \mathrm{~h}-\mathrm{LC}_{50}$ values (95\% CIs) for stage I and II larvae were $43.1 \mu \mathrm{g} / \mathrm{L}(13.0-131.0 \mu \mathrm{g} / \mathrm{L})$ and $20.5 \mu \mathrm{g} / \mathrm{L}$ $(13.2-30.9 \mathrm{mg} / \mathrm{L})$, respectively, representing approximately 2 - and fivefold dilutions of the treatment concentration $(100 \mu \mathrm{g} / \mathrm{L})$ used on Norwegian fish farms. For deltamethrin the $1 \mathrm{~h}-\mathrm{LC}_{50}$ values (with 95\% CIs) for stage I and II larvae were estimated to be $2.6 \mathrm{ng} / \mathrm{L}(0.6-11.0 \mathrm{ng} / \mathrm{L})$ and $2.9 \mathrm{ng} / \mathrm{L}$ (1.5-5.7 ng/L), representing approximately 800 -fold dilution of the treatment concentration of $2000 \mathrm{ng} / \mathrm{L}$. Considering the sensitivity of krill towards $\mathrm{H}_{2} \mathrm{O}_{2}$ found in the present study, where the $\mathrm{LC}_{50}$ ranged from 52- to 2000-fold dilution with increasing post-exposure period, impact zones like those 
calculated for deltamethrin in Parsons et al. (2020) will be most relevant for impact zones for $\mathrm{H}_{2} \mathrm{O}_{2}$ and krill.

Meganyctiphanes norvegica can be found around the North Atlantic, with the Norwegian sea being a major hotspot for its distribution (Melle et al. 2004). Due to their distribution, krill can often be found in waters close to aquaculture sites and therefore be negatively impacted by the dispersal of effluent plumes after treatments. Based on our findings and the information from previous mathematical models, $\mathrm{H}_{2} \mathrm{O}_{2}$ may cause a larger impact than it was previously believed. Therefore, that some cases of mass mortality of krill observed in past years may have been caused by $\mathrm{H}_{2} \mathrm{O}_{2}$ exposure, cannot be overlooked.

Acknowledgements This work was funded by the Norwegian Institute of Marine Research /Havforskningsinstituttet internal funding (Project \# 14907) led by O.B.S. We thank all staff at IMR Austevoll for their assistance with these experiments, in particular Florian Freytet.

Funding Open Access funding provided by Institute Of Marine Research.

Open Access This article is licensed under a Creative Commons Attribution 4.0 International License, which permits use, sharing, adaptation, distribution and reproduction in any medium or format, as long as you give appropriate credit to the original author(s) and the source, provide a link to the Creative Commons licence, and indicate if changes were made. The images or other third party material in this article are included in the article's Creative Commons licence, unless indicated otherwise in a credit line to the material. If material is not included in the article's Creative Commons licence and your intended use is not permitted by statutory regulation or exceeds the permitted use, you will need to obtain permission directly from the copyright holder. To view a copy of this licence, visit http://creativecommons.org/licenses/by/4.0/.

\section{References}

Aaen SM, Aunsmo A, Horsberg TE (2014) Impact of hydrogen peroxide on hatching ability of egg strings from salmon lice (Lepeophtheirus salmonis) in a field treatment and in a laboratory study with ascending concentrations. Aquaculture 422:167-171

Aitken JJ (1960) Swarming in Meganyctiphanes norvegica (M. Sars) in Strangford Lough, Co. Down. Ir Nat J 13:140-142

Bechmann RK, Arnberg M, Gomiero A, Westerlund S, Lyng E, Berry M, Agustsson T, Jager T, Burridge LE (2019) Gill damage and delayed mortality of Northern shrimp (Pandalus borealis) after short time exposure to anti-parasitic veterinary medicine containing hydrogen peroxide. Ecotoxicol Environ Saf 180:473-482

Bravo S, Silva MT, Agusti C, Sambra K, Horsberg TE (2015) The effect of chemotherapeutic drugs used to control salmon louse on the hatching viability of egg strings from Caligus rogercresseyi. Aquaculture 443:77-83

Brodie PF, Sameoto DD, Sheldon RW (1978) Population densities of euphausiids off Nova Scotia as indicated by net samples, whale stomach contents, and sonar. Limnol Oceanogr 23(6):1264-1267

Brokke KE (2015) Mortality caused by de-licing agents on the nontarget organisms chameleon shrimp (Praunus flexuosus) and grass prawns (Palaemon elegans). M.Sc. Thesis, University of Bergen, Bergen, Norway
Bruno DW, Raynard RS (1994) Studies on the use of hydrogen peroxide as a method for the control of sea lice on Atlantic salmon. Aquacult Int 2(1):10-18

Burridge L, Weis JS, Cabello F, Pizarro J, Bostick K (2010) Chemical use in salmon aquaculture: a review of current practices and possible environmental effects. Aquaculture 306(1-4):7-23

Burridge LE, Lyons MC, Wong DKH, MacKeigan K, VanGeest JL (2014) The acute lethality of three anti-sea lice formulations: AlphaMax®, Salmosan®, and Interox ${ }^{\circledR}$ Paramove ${ }^{\mathrm{TM}} 50$ to lobster and shrimp. Aquaculture 420:180-186

Cotran RS, Kumar V, Robbins SL (1989) Pathological basis of disease, 4th edn. Saunders, Toronto

Costello MJ (2006) Ecology of sea lice parasitic on farmed and wild fish. Trends Parasitol 22(10):475-483. https://doi.org/10.1016/j. pt.2006.08.006

Costello MJ (2009) The global economic cost of sea lice to the salmonid farming industry. J Fish Dis 32(1):115-118

Cox SJ (1975) Shore stranding of Meganyctiphanes norvegica (M. Sars). Estuar Coast Mar Sci 3:483-484

Ernst W, Jackman P, Doe K, Page F, Julien G, MacKay K, Sutherland $\mathrm{T}$ (2001) Dispersion and toxicity to non-target aquatic organisms of pesticides used to treat salmon louse on salmon in net pen enclosures. Mar Pollut Bull 42(6):432-443

Escobar-Lux RH, Fields DM, Browman HI, Shema SD, Bjelland RM, Agnalt AL, Skiftesvik AB, Samuelsen OB, Durif CM (2019) The effects of hydrogen peroxide on mortality, escape response, and oxygen consumption of Calanus spp. FACETS 4(1):626-637

Escobar-Lux RH, Parsons AE, Samuelsen OB, Agnalt AL (2020) Short-term exposure to hydrogen peroxide induces mortality and alters exploratory behaviour of European lobster (Homarus gammarus). Ecotoxicol Environ Saf 204:111111

Fagereng MB (2016) Bruk Av Hydrogenperoksid i Oppdrettsanlegg; fortynningstudier Og Effekter På blomsterreke (Pandalus montagui), M.Sc. Thesis. University of Bergen, Norway, p. 104. https://bora.uib.no/handle/1956/13008. (In Norwegian)

Fairchild WL, Doe KG, Jackman PM, Arsenault JT, Aubé JG, Losier M, Cook AM (2010) Acute and chronic toxicity of two formulations of the pyrethroid pesticide deltamethrin to an amphipod, sand shrimp and lobster larvae. Can Tech Rep Fish Aquat Sci 2876:34p

Fang J, Samuelsen OB, Strand Ø, Jansen H (2018) Acute toxic effects of hydrogen peroxide, used for salmon lice treatment, on the survival of polychaetes Capitella sp. and Ophryotrocha spp. Aquac Environ Interact 10:363-368

Finney DJ (1971) Probit analysis, 3rd edn. Cambridge University Press, Cambridge

Finstad B, Bjørn PA, Grimnes A, Hvidsten NA (2000) Laboratory and field investigations of salmon lice [Lepeophtheirus salmonis (Krøyer)] infestation on Atlantic salmon (Salmo salar L.) postsmolts. Aquac Res 31(11):795-803

Gebauer P, Paschke K, Vera C, Toro JE, Pardo M, Urbina M (2017) Lethal and sub-lethal effects of commonly used anti-salmon louse formulations on non-target crab Metacarcinus edwardsii larvae. Chemosphere 185:1019-1029

Grefsrud ES, Svåsand T, Glover K, Husa V et al. (2019) Risikorapport norsk fiskeoppdrett 2019. Fisken og havet, særnr. 1-2019. Havforskningsinstituttet, Bergen. https://www.hi.no/hi/nettr apporter/fisken-og-havet-2019-5. (In Norwegian)

Grover RS (1952) Continuous plankton records: the Euphausiacea of the Northeastern Atlantic and North Sea 1946-48: Hull Bull. Mar Ecol 3(23):185-214

González MP, Marín SL, Vargas-Chacoff L (2015) Effects of Caligus rogercresseyi (Boxshall and Bravo, 2000) infestation on physiological response of host Salmo salar (Linnaeus 1758): Establishing physiological thresholds. Aquaculture 438:47-54 
Hansen BH, Hallmann A, Altin D, Jensen BM, Ciesielski M (2017) Acute hydrogen peroxide $\left(\mathrm{H}_{2} \mathrm{O}_{2}\right)$ exposure does not cause oxidative stress in late-copepodite stages of Calanus finmarchicus. $\mathrm{J}$ Toxicol Environ Health A 80(16-18):820-829

Haugland BT, Rastrick SP, Agnalt AL, Husa V, Kutti T, Samuelsen OB (2019) Mortality and reduced photosynthetic performance in sugar kelp Saccharina latissima caused by the salmonlice therapeutant hydrogen peroxide. Aquac Environ Interact 11:1-17

Johnson SC, Bravo S, Nagasawa K, Kabata Z, Hwang J, Ho J, Shih CT (2004) A review of the impact of parasitic copepods on marine aquaculture. Zool Stud 43(2):229-243

Kaartvedt S, Larsen T, Hjelmseth K, Onsrud MS (2002) Is the omnivorous krill Meganyctiphanes norvegica primarily a selectively feeding carnivore? Mar Ecol Prog Ser 228:193-204

Kaartvedt S, Røstad A, Fiksen Ø, Melle W, Torgersen T, Breien MT, Klevjer TA (2005) Piscivorous fish patrol krill swarms. Mar Ecol Prog Ser 299:1-5

Lindley JA (1982) Population dynamics and production of euphausiids. Mar Biol 66(1):37-46

Lyons MC, Wong DKH, Page FH (2014) Degradation of hydrogen peroxide in seawater using the anti-sea louse formulation interox paramove 50. Fisheries and Oceans Canada, Maritimes Region, St. Andrews Biological Station

Macdonald R (1927) Food and habits of Meganyctiphanes norvegica. J Mar Biol Assoc U K 14(3):753-784

Medina M, Barata C, Telfer T, Baird DJ (2004) Assessing the risks to zooplankton grazers of continuous versus pulsed cypermethrin exposures from marine cage aquaculture. Arch Environ Contam Toxicol 47(1):67-73

Melle W, Ellertsen B, Skjoldal HR (2004) Zooplankton: the link to higher trophic levels. The Norwegian Sea ecosystem. Tapir Academic Press, Trondheim, pp 137-202

Montevecchi WA, Birt-Friesen VL, Cairns DK (1992) Reproductive energetics and prey harvest of Leach's storm-petrels in the northwest Atlantic. Ecology 73(3):823-832

Onsrud MSR, Kaartvedt S, Røstad A, Klevjer TA (2004) Vertical distribution and feeding patterns in fish foraging on the krill Meganyctiphanes norvegica. ICES J Mar Sci 61(8):1278-1290

Parsons AE, Escobar-Lux RH, Sævik PN, Samuelsen OB, Agnalt AL (2020) The impact of anti-sea lice pesticides, azamethiphos and deltamethrin, on European lobster (Homarus gammarus) larvae in the Norwegian marine environment. Environ Pollut. https://doi. org/10.1016/j.envpol.2020.114725

Refseth GH, Sæther K, Drivdal M, Nøst OA, Augustine S, Camus L, Tassara L, Agnalt A-L, Samuelsen OB (2017) Miljørisiko ved bruk Av Hydrogenperoksid. Økotoksikologisk vurdering Og Grenseverdi for Effekt. Assessment. CRC Press, Boca Raton. https ://www.fhf.no/prosjekter/prosjektbasen/901249/. (In Norwegian)

Sameoto D, Neilson J, Waldron D (1994) Zooplankton prey selection by juvenile fish in Nova Scotian Shelf basins. J Plankton Res 16(8):1003-1019

Smit MG, Ebbens E, Jak RG, Huijbregts MA (2008) Time and concentration dependency in the potentially affected fraction of species: the case of hydrogen peroxide treatment of ballast water. Environ Toxicol Chem 27(3):746-753

Stevick PT, Incze LS, Kraus SD, Rosen S, Wolff N, Baukus A (2008) Trophic relationships and oceanography on and around a small offshore bank. Mar Ecol Prog Ser 363:15-28

Stratford HK, Quimby PC, Ouzts JD (1984) Photo enchancement of hydrogen peroxide toxicity to submersed vascular plants and algae. Aquat Plant Manage 22:25-34

Tarling GA, Ensor NS, Fregin T, Goodall-Copestake WP, Fretwell P (2010) An introduction to the biology of northern krill (Meganyctiphanes norvegica Sars). Advances in marine biology, vol 57. Academic Press, Cambridge, pp 1-40

Torrissen O, Jones S, Asche F, Guttormsen A, Skilbrei OT, Nilsen F, Horsberg TE, Jackson D (2013) Salmon lice-impact on wild salmonids and salmon aquaculture. J Fish Dis 36(3):171-194

Treasure JW, Gran A, Davi PJ (2000) Physical constraints of bath treatments of Atlantic salmon (Salmo salar) with a sea lice burden (Copepoda: Caligidae). Contrib Zool 69(1-2):129-136

Urbina MA, Cumillaf JP, Paschke K, Gebauer P (2019) Effects of pharmaceuticals used to treat salmon lice on non-target species: evidence from a systematic review. Sci Total Environ 649:1124-1136

Van Geest JL, Burridge LE, Fife FJ, Kidd KA (2014) Feeding response in marine copepods as a measure of acute toxicity of four antisalmon louse pesticides. Mar Environ Res 101:145-152

Vollset KW, Barlaup BT, Mahlum S, Bjørn PA, Skilbrei OT (2016) Estimating the temporal overlap between post-smolt migration of Atlantic salmon and salmon lice infestation pressure from fish farms. Aquac Environ Interact 8:511-525

Wiborg KF (1966) Unders $\varnothing$ kelser av krill (lyskreps) i Hardangerfjorden og tilstøtende områder, samt på stasjon $\mathrm{M}$ i Norskehavet. Fiskets Gang 41(754):761 (In Norwegian)

Publisher's Note Springer Nature remains neutral with regard to jurisdictional claims in published maps and institutional affiliations. 